\title{
The impact of the year-on-year variation in the intensity of solar radiation on the energy intensity of low-energy and passive houses
}

\author{
Roman Šbrt ${ }^{1, *}$ and Pavlína Charvátová ${ }^{2}$ \\ ${ }^{1}$ Energy Consulting, z.s. Alešova 21, 37001 České Budějovice, Czech Republic \\ ${ }^{2}$ Institute of Technology and Business in České Budějovice, Department of Civil Engineering, \\ 370 01, České Budějovice, Czech Republic
}

\begin{abstract}
Solar radiation is a significant segment of heat gains in the operation of buildings. The importance of this segment is highlighted by lowering the energy performance of buildings. The current condition of assessment considers the standard values of solar radiation but these are often very different from the fair values. In the contribution it draws attention to not only to on-year variation in solar fluctuations in the intensity of solar radiation and its significant long-term deviation from the standard values but also to the impact to energy building in reliance to its energy intensity. The attention will be focused also to different values in standards valid in the Czech Republic. This specification of energy assessment of buildings is not only necessary to approximate calculations of real state, but mainly because we can expect more disputes about if a building has declared calculating the parameters of a building with nearly zero-energy or passive house.
\end{abstract}

\section{Current condition in the Czech Republic}

Energy performance of buildings is assessed by calculations according to valid European standards taking into consideration the climatic data in the Czech Republic. Those are given by CSN 730540 (CSN = Czech Technical Standard) and TNI 730331 (TNI = Technical Standards Information) and they should be based on long-term average. Even though TSI is just a recommended information usually the values listed there are used for assessment of buildings. Although the information differs in both standards and mainly in global radiation perpendicular surface oriented to different cardinal points. Comparison for the winter season is shown in Table 1 where there is a noticeable difference both in individual months, and within different orientation to cardinal points. These different values lead to according TNI it is less necessary to consider the orientation of windows to different cardinal points than when evaluation by CSN. Another source of values of global solar radiation for the region of the Czech Republic can be obtained from the Internet, namely from the computational programs for calculation of electricity from photovoltaic power plants.

\footnotetext{
${ }^{*}$ Corresponding author: roman@e,e-c.cz
} 
In Table 2 shows the comparison of results of several houses and different assessment according to these standards.

\section{Real climate data}

To determine the actual status of global radiation the data were purchased from ČHMÚ (Czech Hydrometeorological Institute) which performs long-term measurements. Values for Hradec Králové are listed in Table 3 [1]. This table shows that global solar radiation over the past 10 years is higher than the long-term average which is given in CSN, although the global radiation does not correspond with average temperatures for that period.

Table 1. Comparison of values listen in TNI 730331 and CSN 73 0540-3.

\begin{tabular}{|c|c|c|c|c|c|c|c|c|}
\hline \multirow{2}{*}{ source } & \multicolumn{8}{|c|}{ Monthly dose irradiation $H\left[\mathrm{kWh} /\left(\mathrm{m}^{2} \bullet\right.\right.$ month $\left.)\right]$} \\
\hline & January & Fabruary & March & April & October & November & December & Total per year \\
\hline \multicolumn{9}{|c|}{ Horizon } \\
\hline ČSN & 23,06 & 36,75 & 76,12 & 110,53 & 52,74 & 25,53 & 18,62 & 343,35 \\
\hline TNI & 20,8 & 37,0 & 72,2 & 113,8 & 56,5 & 25,2 & 14,9 & 340,4 \\
\hline difference & $90 \%$ & $101 \%$ & $95 \%$ & $103 \%$ & $107 \%$ & $99 \%$ & $80 \%$ & $99 \%$ \\
\hline \multicolumn{9}{|c|}{ South } \\
\hline ČSN & 41,94 & 53,31 & 89,73 & 88,42 & 71,57 & 41,07 & 30,95 & 416,99 \\
\hline TNI & 34,2 & 51,1 & 74,4 & 84,7 & 74,4 & 45,4 & 29,0 & 393,2 \\
\hline difference & $82 \%$ & $96 \%$ & $83 \%$ & $96 \%$ & $104 \%$ & $111 \%$ & $94 \%$ & $94 \%$ \\
\hline \multicolumn{9}{|c|}{ Southeast, Southwest } \\
\hline ČSN & 32,2 & 41,17 & 76,16 & 84,33 & 57,61 & 31,99 & 23,86 & 347,32 \\
\hline TNI & 26,8 & 41,0 & 64,7 & 86,4 & 60,3 & 33,8 & 23,1 & 336,1 \\
\hline difference & $83 \%$ & $100 \%$ & $85 \%$ & $102 \%$ & $105 \%$ & $106 \%$ & $97 \%$ & $97 \%$ \\
\hline \multicolumn{9}{|c|}{ East, West } \\
\hline ČSN & 15,01 & 22,21 & 48,89 & 65,84 & 32,23 & 15,87 & 11,18 & 211,23 \\
\hline TNI & 14,1 & 25,5 & 46,9 & 74,2 & 38,7 & 18,0 & 11,2 & 228,6 \\
\hline difference & $94 \%$ & $115 \%$ & $96 \%$ & $113 \%$ & $120 \%$ & $113 \%$ & $100 \%$ & $108 \%$ \\
\hline \multicolumn{9}{|c|}{ Northeast, Northwest } \\
\hline ČSN & 6,42 & 9,55 & 23,25 & 38,3 & 14,06 & 6,98 & 5,09 & 103,65 \\
\hline TNI & 8,2 & 14,8 & 29,8 & 50,4 & 21,6 & 9,4 & 6,0 & 140,2 \\
\hline difference & $128 \%$ & $155 \%$ & $128 \%$ & $132 \%$ & $154 \%$ & $135 \%$ & $118 \%$ & $135 \%$ \\
\hline \multicolumn{9}{|c|}{ North } \\
\hline ČSN & 5,21 & 7,26 & 15,6 & 24,04 & 10,36 & 5,52 & 4,03 & 72,02 \\
\hline TNI & 8,2 & 13,4 & 25,3 & 36,0 & 18,6 & 9,4 & 6,0 & 116,9 \\
\hline difference & $157 \%$ & $185 \%$ & $162 \%$ & $150 \%$ & $180 \%$ & $170 \%$ & $149 \%$ & $162 \%$ \\
\hline
\end{tabular}


Table 2. Comparison of assessment Building Energy Performance for heating depending on weather data according to CSN 730540 and according to TNI 730331 [GJ].

\begin{tabular}{|c|c|c|c|}
\hline & A4 & B4 & C4 \\
\hline ČSN & 32,5 & 31,4 & 30,4 \\
\hline TNI & 31,3 & 30,0 & 29,2 \\
\hline difference $\%$ & 4 & 4 & 4 \\
\hline
\end{tabular}

\section{Comparison of the calculated values}

To determine the difference of the actual climate data was chosen reference building with dimensions of $10 \times 10 \mathrm{~m}$ and $6 \mathrm{~m}$ in height with windows of $20 \mathrm{~m}^{2}$ facing south, $4 \mathrm{~m}^{2}$ north and after $8 \mathrm{~m}^{2}$ on the east and west. This building was considered a total of 12 variants, according to storage capacity of construction:
A) Lightweight construction, heat capacity $110 \mathrm{~kJ} /\left(\mathrm{K} \cdot \mathrm{m}^{2}\right)$,
B) Medium-heavy construction, heat capacity $165 \mathrm{~kJ} /\left(\mathrm{K} \cdot \mathrm{m}^{2}\right)$,
C) Heavy construction, heat capacity $260 \mathrm{~kJ} /\left(\mathrm{K} \cdot \mathrm{m}^{2}\right)$.

And also according to quality of thermal insulations. There were chosen values required by standard of 1964 [2], by standard of 1977 and also recommended values for passive houses by standard from 2011. These values are listen in Table 4, where ale also listed characteristic values of the glazing. Ventilation in the first two cases is considered natural, in the latter two cases is considered as a forced recovery.

Table 3. Global solar radiation for years 2005 - 2014 measured in Hradec Králové.

\begin{tabular}{|c|c|c|c|c|c|c|c|c|c|c|}
\hline \multicolumn{9}{|c|}{ Global solar radiation $E_{\mathrm{m}}\left[\mathrm{kWh} /\left(\mathrm{m}^{2} \cdot \mathrm{month}\right)\right]$} & \multirow{2}{*}{$\begin{array}{c}\text { How much } \\
\text { more sunlight } \\
\text { strikes } \\
\text { against CSN } \\
{[\%]} \\
\end{array}$} & \multirow{2}{*}{$\begin{array}{c}\text { How many } \\
\text { degree-days } \\
\text { were warmer } \\
\text { comparing to } \\
\text { the long-term } \\
\text { average [\%] }\end{array}$} \\
\hline year & 01 & 02 & 03 & 04 & 10 & 11 & 12 & $\begin{array}{l}\text { Total } \\
\text { year }\end{array}$ & & \\
\hline 2005 & 28,20 & 43,80 & 100,22 & 135,25 & 73,92 & 22,65 & 15,27 & 419,30 & $122 \%$ & $107 \%$ \\
\hline 2006 & 32,48 & 44,55 & 79,49 & 120,45 & 68,51 & 25,45 & 19,64 & 390,56 & $114 \%$ & $113 \%$ \\
\hline 2007 & 23,99 & 39,45 & 81,48 & 165,44 & 58,55 & 26,35 & 15,69 & 410,95 & $120 \%$ & $126 \%$ \\
\hline 2008 & 23,93 & 47,34 & 82,08 & 114,97 & 56,65 & 26,24 & 19,49 & 370,69 & $108 \%$ & $117 \%$ \\
\hline 2009 & 24,73 & 33,47 & 64,51 & 162,50 & 41,40 & 29,44 & 17,31 & 373,35 & $109 \%$ & $118 \%$ \\
\hline 2010 & 26,29 & 40,49 & 86,35 & 140,36 & 67,89 & 24,64 & 17,71 & 403,72 & 11 & 98 \\
\hline 2011 & 25,21 & 47,80 & 102,62 & 127,84 & 61,22 & 30,11 & 17,63 & 42 & 12 & 11 \\
\hline 2012 & 26,60 & 48,24 & 99,32 & 124,66 & 53,06 & 25,02 & 20,69 & $\mathbf{3 9 7 , 5 9}$ & $116 \%$ & $117 \%$ \\
\hline 2013 & 18,46 & 34,40 & 76,87 & 105,94 & 67,91 & 24,25 & 20,41 & 348 & $101 \%$ & $111 \%$ \\
\hline 2014 & 23,82 & 48,46 & 96,43 & 126,57 & 56,90 & 21,34 & 15,86 & 389,38 & $113 \%$ & $138 \%$ \\
\hline CSN & 23,06 & 36,75 & 76,12 & 110,53 & 52,74 & 25,53 & 18,62 & 343,35 & $100 \%$ & \\
\hline
\end{tabular}


Table 4. Considered in the calculation of thermal properties of the reference building.

\begin{tabular}{|l|c|c|c|c|}
\hline \multirow{2}{*}{ construction } & \multicolumn{5}{|c|}{ heat transfer coefficient $U_{\mathrm{N}}\left[\mathrm{W} /\left(\mathrm{m}^{2} \cdot \mathrm{K}\right)\right]$} \\
\cline { 2 - 6 } & $\begin{array}{c}\text { CSN 73 0540 } \\
\text { of } 1964\end{array}$ & $\begin{array}{c}\text { CSN 73 0540 } \\
\text { of } 1977\end{array}$ & $\begin{array}{c}\text { CSN 73 0540-2 } \\
\text { recommended } \\
\text { values }\end{array}$ & $\begin{array}{c}\text { CSN 73 0540-2 } \\
\text { recommended values } \\
\text { for passive houses }\end{array}$ \\
\cline { 2 - 6 } & $\mathbf{1}$ & $\mathbf{2}$ & $\mathbf{3}$ & $\mathbf{4}$ \\
\hline on the ground floor & 1,5 & 1,15 & 0,3 & 0,15 \\
\hline wall & 1,4 & 0,89 & 0,25 & 0,12 \\
\hline window & 2,4 & 2,4 & 1,1 & 0,9 \\
\hline flat floor & 0,93 & 0,51 & 0,16 & 0,1 \\
\hline solar transmittance glass g [-]: & 0,81 & 0,81 & 0,52 & 0,6 \\
\hline
\end{tabular}

Table 5. Calculated energy performance of buildings according to climate conditions CSN 730540 and according to climate data in each years for region Hradec Králové [GJ].

\begin{tabular}{|c|c|c|c|c|c|c|c|c|c|c|c|c|}
\hline & $\mathbf{A 1}$ & $\mathbf{A 2}$ & $\mathbf{A 3}$ & $\mathbf{A 4}$ & $\mathbf{B 1}$ & $\mathbf{B 2}$ & $\mathbf{B 3}$ & $\mathbf{B 4}$ & $\mathbf{C 1}$ & $\mathbf{C 2}$ & $\mathbf{C 3}$ & $\mathbf{C 4}$ \\
\hline 2005 & 184,7 & 126,1 & 46,9 & 28,8 & 182,2 & 123,5 & 45,1 & 27,7 & 179,2 & 120,2 & 43,2 & 26,9 \\
\hline 2006 & 183,8 & 125,8 & 46,8 & 28,9 & 181,4 & 123,3 & 45,1 & 27,8 & 178,2 & 120,1 & 43,3 & 26,9 \\
\hline 2007 & 164,6 & 111,9 & 40,2 & 25,6 & 162,1 & 109,1 & 38,3 & 24,1 & 159,2 & 106,4 & 37,2 & 23,2 \\
\hline 2008 & 164,3 & 111,5 & 39,6 & 24,6 & 162,0 & 109,1 & 38,1 & 23,2 & 159,2 & 106,1 & 36,8 & 21,9 \\
\hline 2009 & 179,5 & 123,1 & 47,0 & 30,0 & 177,3 & 121,0 & 45,5 & 29,2 & 174,6 & 118,7 & 43,3 & 28,5 \\
\hline 2010 & 195,6 & 134,6 & 50,9 & 32,8 & 193,4 & 132,3 & 49,2 & 30,9 & 190,3 & 129,6 & 47,5 & 29,7 \\
\hline 2011 & 178,7 & 121,4 & 44,3 & 26,4 & 176,2 & 118,4 & 42,4 & 25,1 & 173,2 & 115,6 & 40,6 & 23,7 \\
\hline 2012 & 181,5 & 123,5 & 45,3 & 26,3 & 179,2 & 120,8 & 43,5 & 24,9 & 176,5 & 118,3 & 41,9 & 23,6 \\
\hline 2013 & 189,1 & 130,2 & 49,0 & 31,1 & 186,6 & 127,7 & 47,4 & 29,6 & 184,4 & 125,5 & 45,9 & 28,3 \\
\hline 2014 & 151,0 & 101,3 & 36,5 & 22,4 & 148,6 & 99,0 & 34,6 & 20,4 & 145,7 & 96,3 & 33,0 & 19,1 \\
\hline CSN & 182,7 & 127,1 & 49,1 & 32,5 & 180,8 & 125,2 & 47,8 & 31,4 & 178,7 & 122,7 & 46,7 & 30,4 \\
\hline
\end{tabular}

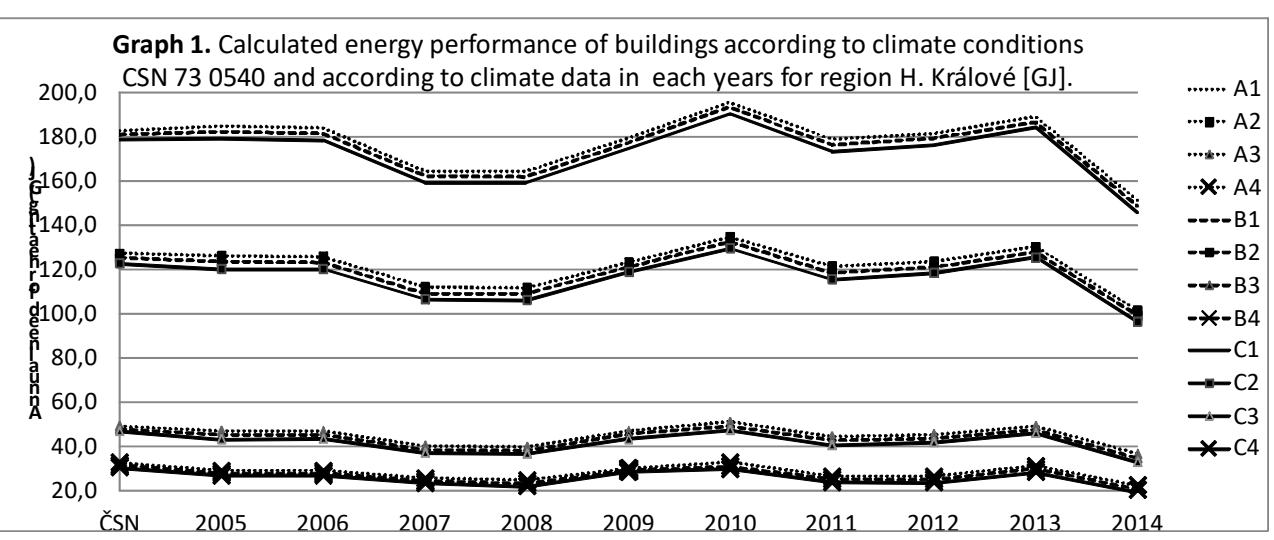

Fig. 1. Calculated energy performance of buildings according to climate conditions CSN 730540 and according to climate data in each years for region Hradec Králové [GJ]. 
Calculations of energy performance of buildings for heating were done according to CSN EN ISO 13790 and the result is 12 variants of calculation (from A1 to C4) for years 2005 - 2014. These results are listed in Table 5 and later in graph 1 [3].

In Table 6 and graph 2 are then calculated values in percentage relative to the values calculated according to the standard.

Table 6. Energy performance of buildings according to climate data in each years for the region Hradec Králové relative in percentage to values obtained under standardized climatic conditions [\%].

\begin{tabular}{|c|c|c|c|c|c|c|c|c|c|c|c|c|}
\hline & $\mathbf{A 1}$ & $\mathbf{A 2}$ & $\mathbf{A 3}$ & $\mathbf{A 4}$ & $\mathbf{B 1}$ & $\mathbf{B 2}$ & $\mathbf{B 3}$ & $\mathbf{B 4}$ & $\mathbf{C 1}$ & $\mathbf{C 2}$ & $\mathbf{C 3}$ & $\mathbf{C 4}$ \\
\hline 2005 & 101,1 & 99,2 & 95,6 & 88,6 & 100,8 & 98,6 & 94,2 & 88,3 & 100,3 & 97,9 & 92,5 & 88,4 \\
\hline 2006 & 100,6 & 98,9 & 95,5 & 88,9 & 100,3 & 98,5 & 94,3 & 88,6 & 99,8 & 97,8 & 100,2 & 95,1 \\
\hline 2007 & 90,1 & 88,0 & 82,0 & 78,8 & 89,7 & 87,1 & 80,1 & 76,9 & 89,1 & 86,7 & 79,6 & 76,4 \\
\hline 2008 & 90,0 & 87,7 & 80,7 & 75,8 & 89,6 & 87,1 & 79,7 & 73,9 & 89,1 & 86,5 & 78,6 & 72,2 \\
\hline 2009 & 98,3 & 96,8 & 95,8 & 92,3 & 98,0 & 96,7 & 95,2 & 92,9 & 97,7 & 96,7 & 92,6 & 93,9 \\
\hline 2010 & 107,1 & 105,9 & 103,8 & 101,1 & 106,9 & 105,7 & 102,8 & 98,3 & 106,5 & 105,6 & 101,6 & 97,7 \\
\hline 2011 & 97,8 & 95,5 & 90,4 & 81,4 & 97,4 & 94,5 & 88,7 & 80,0 & 97,0 & 94,1 & 86,8 & 78,0 \\
\hline 2012 & 99,4 & 97,1 & 92,4 & 81,1 & 99,1 & 96,5 & 91,0 & 79,4 & 98,8 & 96,4 & 89,6 & 77,6 \\
\hline 2013 & 103,5 & 102,4 & 99,9 & 95,7 & 103,2 & 102,0 & 99,1 & 94,3 & 103,2 & 102,2 & 98,2 & 93,2 \\
\hline 2014 & 82,7 & 79,7 & 74,5 & 68,8 & 82,2 & 79,1 & 72,3 & 65,0 & 81,5 & 78,5 & 70,6 & 62,9 \\
\hline CSN & 100,0 & 100,0 & 100,0 & 100,0 & 100,0 & 100,0 & 100,0 & 100,0 & 100,0 & 100,0 & 100,0 & 100,0 \\
\hline
\end{tabular}

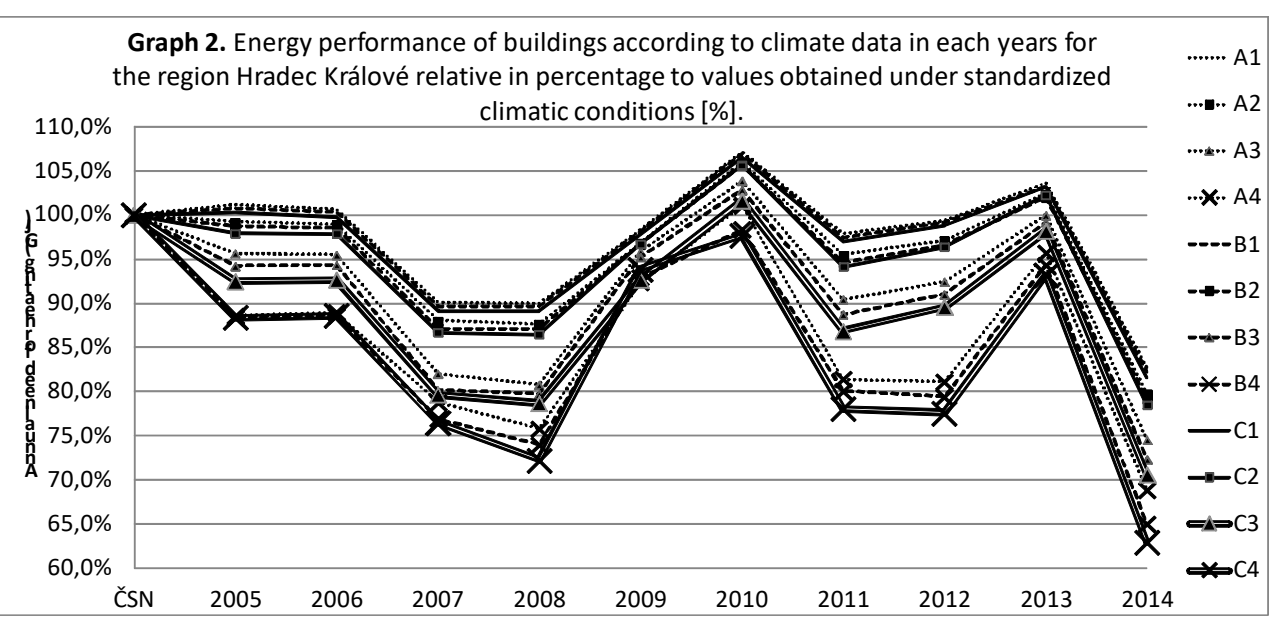

Fig. 2. Energy performance of buildings according to climate data in each years for the region Hradec Králové relative in percentage to values obtained under standardized climatic conditions [\%].

Effect of changes in the intensity of solar radiation on energy consumption for heating is documented in Table 7 and graph 3 . There is calculated energy consumption for heating according to values listed in the standard and then is considered the same temperature, however the intensity of solar radiation is higher by $20 \%$. 
Table 7. Energy performance of buildings according to climate data according to the standard and increase in the global solar radiation by $20 \%$ for the region Hradec Králové listed in GJ and in \% relative to standard values.

\begin{tabular}{|c|c|c|c|c|c|c|c|c|c|c|c|c|}
\hline & A1 & A2 & A3 & A4 & B1 & B2 & B3 & B4 & C1 & C2 & C3 & C4 \\
\hline CSN [GJ] & 182,7 & 127,1 & 49,1 & 32,5 & 180,8 & 125,2 & 47,8 & 31,4 & 178,7 & 122,7 & 46,7 & 30,4 \\
\hline $\begin{array}{c}\text { Temperatures according to } \\
\text { CSN, sun more by 20\% [GJ] }\end{array}$ & 176,6 & 121,1 & 45,7 & 29,3 & 174,4 & 118,2 & 44,3 & 28,1 & 171,8 & 116,1 & 42,8 & 27,0 \\
\hline Likewise \% & 103,5 & 105,0 & 107,3 & 111,0 & 103,7 & 105,9 & 108,1 & 111,9 & 104,0 & 105,8 & 109,3 & 112,7 \\
\hline
\end{tabular}

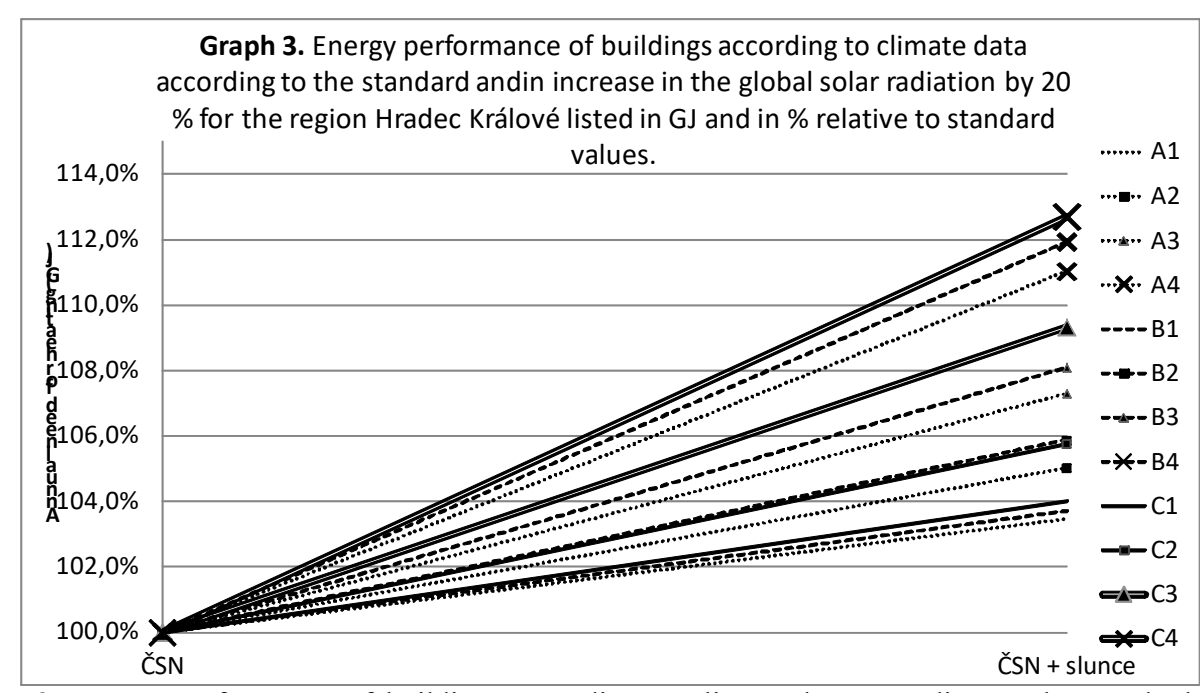

Fig. 3. Energy performance of buildings according to climate data according to the standard and increase in the global solar radiation by $20 \%$ for the region Hradec Králové listed in GJ and in \% relative to standard values.

\section{Conclusions}

The results demonstrate clearly that the effect of fluctuations in solar radiation has a significant influence to energy performance of buildings for heating which increases especially with thermal insulation properties structure. In old buildings, the $20 \%$ difference in the global radiation shows at model building the range of 3,5 to $4 \%$ depending on the heat capacity of the considered structure. For buildings with thermal insulation as recommended for passive houses, however, the difference is 11 to $12,7 \%$. From this finding it implies knowledge that when assesing the measured energy consumption for heating is necessary, besides other things, také in account also global solar radiation, which is usually not performed, usually only takes into account the different temperatures in the heating season. Less significant impact on the energy performance of buildings have storage capabilites. Those at the model house ranged to $2,3 \%$.

\section{References}

1. R. Šubrt, P. Charvátová, Climatic data from 07/2014 to 06/2015 (AES, 2015)

2. ČSN 73 0540, Thermal protection of buildings (1964)

3. R. Šubrt, P. Charvátová, Katalog tepelných vazeb II - vnější stěny (Isover, Prague, 2015) 